\title{
HUBUNGAN KUAT TEKAN BETON ANTARA HASIL UJI TEKAN KUBUS DAN UJI TEKAN SILINDER PADA BETON DENGAN AGREGAT PULAU TIMOR
}

\author{
I Gusti Ngurah Eka Partamal), Rani Hendrikus ${ }^{2)}$, Amandus H. W. Galus ${ }^{3)}$ \\ E-mail:epartama@gmail.com ${ }^{1)}$,rani.hendrikus@gmail.com ${ }^{2}$,wantogalus@yahoo.com ${ }^{3)}$ \\ 1)Prodi Teknik Sipil UNR Denpasar, ${ }^{2}$ Prodi Teknik Sipil UNWIRA Kupang, ${ }^{3)}$ Alumni Prodi \\ Teknik Sipil UNWIRA Kupang
}

\begin{abstract}
Abstrak
Benda uji silinder atau kubus diperlukan untuk menentukan kuat tekan beton. Benda uji kubus berdimensi $15 \mathrm{~cm} \times 15 \mathrm{~cm} \times 15 \mathrm{~cm}$ sedangkan bentuk silinder berdimensi $15 \mathrm{~cm} \times 30 \mathrm{~cm}$. Ketersediaan cetakan benda uji silinder di lapangan sering tidak terpenuhi karena persediaan yang terbatas dan memaksa seorang tenaga supervisi mengijinkan menggunakan cetakan benda uji kubus untuk menguji mutu beton yang sedang dikerjakan. Sesuai PBI 1971 untuk melakukan konversi kuat tekan beton berdasarkan benda uji kubus sehingga setara dengan kuat tekan beton dengan benda uji silinder dikalikan faktor 0.83 atau menggunakan formula $f^{\prime} c=\left(0,76+0,2 \log \left(f^{\prime} c k / 15\right)\right)$. f'ck (Nugraha, et al, 2007 dan Mulyono, 2003). Agregat alam berupa pasir dan krikil di Pulau Timor alam merupakan batuan endapan bukan merupakan material hasil erupsi gunung api sehingga karakteristiknya berbeda. Kajian dilakukan untuk mengevaluasi faktor konversi 0,83 dan formula $f^{\prime} c=\left(0,76+0,2 \log \left(f^{\prime} c k / 15\right)\right)$. $f^{\prime} c k$ pada beton dengan agregat Pulau Timor. Penelitian dilakukan dengan benda uji beton dengan agregat Quarry Takari di Pulau Timor, berjumlah 30 buah terdiri dari 15 buah berbentuk silinder dan 15 buah berbentuk kubus. Masing-masing mutu beton disiapkan 3 benda uji yaitu untuk mutu K-175, K-200, K-225, K-250 dan K-300. Setelah benda uji dirwat selama 28 hari di laboratorium kemudian dilakukan uji kuat tekan. Hasil ratio rata-rata hubungan kuat tekan benda uji kubus dan silinder beton dengan agregat Pulau Timor sebesar 0.83 dan dalam fungsi regresi linear dengan persamaan $f^{\prime} c=0,822 f^{\prime} c k+0,312$, dimana $f^{\prime} c$ dan $f^{\prime} c k$ dalam MPa dengan nilai slump $30-60 \mathrm{~mm}$ dengan Koefisien korelasi $(r)=0.905$ dan koefisien determinasi $\left(r^{2}\right)=0.819$, menunjukkan $81,90 \%$ nilai kuat tekan beton f'c dapat ditentukan berdasarkan hasil pengujian benda uji kubus dan 18,10\% ditentukan faktor lain. Rata-rata faktor konversi hasil penelitian sebesar 0,83 sama dengan yang dicantumkan dalam PBI 1971 dan formula konversi hasil penelitian : f'c =0,822f'ck+0,312 menunjukkan rerata perbedaan absolut sebesar $0,82 \mathrm{MPa}$ atau 3,17\% dengan formula $f^{\prime} c=\left(0,76+0,2 \log \left(f^{\prime} c k / 15\right)\right) \cdot f^{\prime} c k$.
\end{abstract}

Kata kunci : kuat tekan, kubus, silinder, agregat, Pulau Timor

\section{PENDAHULUAN}

\subsection{Latar Belakang}

Pengujian kuat tekan beton dengan menggunakan benda uji kubus sangat umum digunakan untuk menentukan kuat tekan beton sesuai standar Peraturan Beton Bertulang Indonesia Tahun 1955 (PBI 1955) dan Peraturan Beton Bertulang Indonesia Tahun 1971 (PBI 1971). Setelah diterbitkannya Standar Tata Cara Perhitungan Struktur Beton Untuk Bangunan Gedung (SK SNI T-15-1991-03 dan SNI-03-2847-2002) kuat tekan rencana dinyatakan dengan notasi f'c dengan benda uji silinder.

Benda uji silinder atau benda uji kubus diperlukan untuk menentukan kuat tekan beton. Benda uji kubus berdimensi $15 \mathrm{~cm} \times 15 \mathrm{~cm} \times 15 \mathrm{~cm}$ sedangkan bentuk silinder berdiameter $15 \mathrm{~cm}$ dan tinggi 30 
$\mathrm{cm}$. Ketersediaan cetakan benda uji silinder di lapangan terkadang sulit terpenuhi karena persediaan yang terbatas dan memaksa seorang tenaga supervisi mengijinkan menggunakan cetakan benda uji kubus untuk menguji mutu beton yang sedang dikerjakan. Sesuai PBI 1971 untuk melakukan konversi kuat tekan beton berdasarkan benda uji kubus sehingga setara dengan kuat tekan beton dengan benda uji silinder dikalikan faktor 0.83 atau mengkonversi menggunakan formula $f^{\prime} c=(0,76+$ 0,2log(f'ck/15)).f'ck (Nugraha, et al, 2007 dan Mulyono, 2003)

Agregat alam berupa pasir dan krikil di Pulau Timor alam merupakan batuan endapan bukan merupakan material hasil erupsi gunung api sehingga karakteristiknya berbeda. Perbedaan karakteristik tersebut berpengaruh pada mutu beton, sehingga perlu dilakukan kajian apakah faktor konversi 0,83 dan formula $f^{\prime} c=\left(0,76+0,2 \log \left(f^{\prime} c k / 15\right)\right)$. f'ck sama atau berbeda jika menggunakan agregat Pulau Timor.

\subsection{Rumusan Masalah}

Rumusan masalah pada penelitian ini adalah : bagaimana hubungan kuat tekan beton antara hasil uji tekan kubus dan uji tekan silinder untuk beton menggunakan agregat Pulau Timor?

\subsection{Tujuan Penelitian}

Penelitian ini bertujuan untuk menentukan hubungan kuat tekan beton antara hasil uji tekan kubus dan uji tekan silinder untuk beton dengan agregat di Pulau Timor

\subsection{Manfaat Penelitian}

Manfaat dari penelitian ini adalah untuk melakukan konversi kuat tekan antara hasil kedua metode tersebut (hasil uji kubus dan uji silinder) untuk beton dengan agregat dari Pulau Timor.

\subsection{Batasan Masalah}

Penelitian ini dibatasi dalam lingkup dan pembahasannya sebagai berikut :

1. Agregat Pulau Timor terbatas dari Quarry Takari

2. Benda uji dibuat untuk mutu beton rencana K-175, K-200, K-225, K-250, K-300.

\section{TINJAUAN PUSTAKA}

\subsection{Bahan Penyusun Beton}

Beton umumnya terdiri dari tiga bahan penyusun yaitu semen agregat dan air. Agregat merupakan material seperti pasir, kerikil dan batu pecah yang dipakai bersama-sama dengan suatu 
media pengikat untuk membentuk suatu beton semen hidrolis atau adukan. Agregat secara umum menempati $70 \%$ - $80 \%$ dari volume beton.

\subsubsection{Semen Portland (PC)}

Semen Portland (PC) atau lebih dikenal dengan semen berfungsi sebagai pengikat agregat halus dan agregat kasar apabila tercampur dengan air. Selain itu, semen juga mampu mengisi ronggga antara agregat tersebut.

Kadar kapur yang tinggi tetapi tidak berlebihan cenderung memperlambat pengikatan, tetapi menghasilkan kekuatan awal yang tinggi. Kekurangan zat kapur menghasilkan semen yang lemah, dan bilamana kurang sempurna pembakarannya, menyebabkan ikatan yang cepat (Mulyono, 2003).

Dalam semen pada dasarnya ada 4 senyawa penting, yaitu: Trikalsium Silikat $\left(\mathrm{C}_{3} \mathrm{~S}\right)$, Dikalsium Silikat $\left(\mathrm{C}_{2} \mathrm{~S}\right)$, Trikalsium Aluminat $\left(\mathrm{C}_{3} \mathrm{~A}\right)$ dan Tetrakalsium Aluminoferit $\left(\mathrm{C}_{4} \mathrm{AF}\right)$. Senyawa $\mathrm{C}_{3} \mathrm{~S}$ dan $\mathrm{C}_{2} \mathrm{~S}$ merupakan senyawa penyusun utama dari semen dengan prosentase sekitar $70 \%-80 \%$ yang menyebabkan semen bersifat sebagai perekat, selain itu senyawa ini juga berpengaruh terhadap pengerasan semen. Kadar $\mathrm{C}_{3} \mathrm{~S}$ yang lebih besar dari $\mathrm{C}_{2} \mathrm{~S}$, umumnya menyebabkan semen menjadi cepat mengeras. Semen Portland yang cepat mengeras (Rapid hardening cemen Portland) mengandung kadar $\mathrm{C}_{3} \mathrm{~S}$ yang cukup tinggi, yaitu sekitar $60 \%$.

Senyawa $\mathrm{C}_{3} \mathrm{~A}$ jika bercampur dengan air akan mengalami hidrasi sangat cepat disertai dengan pelepasan sejumlah panas dan kemudian hancur. Oleh karena itu senyawa ini tidak mempunyai sifat mengikat. Kandungan senyawa $\mathrm{C}_{3} \mathrm{~A}$ yang lebih besar dari $18 \%$ mengakibatkan semen menjadi tidak kekal bentuk karena sifatnya yang hancur, sehingga menjadikan semen mengembang pada waktu pengerasan. Senyawa yang keempat $\mathrm{C}_{4} \mathrm{AF}$ senyawa yang memperlambat pengerasan jika kadarnya tinggi.

\subsubsection{Agregat}

Agregat berfungsi sebagai bahan pengisi dalam campuran beton yang mengisi $70 \%-80 \%$ volume beton, sehingga sangat berpengaruh terhadap sifat-sifat beton. Faktor yang mempengaruhi kekuatan agregat pada beton yaitu kekerasan agregat, kekasaran permukaan agregat dan gradasi agregat. Pada agregat dengan permukaan kasar akan terjadi ikatan yang baik antara pasta semen dengan agregat tersebut. Batu pecah yang memiliki permukaan yang lebih kasar daripada kerikil sehingga memberikan kuat tekan yang lebih tinggi pada beton (Tjokrodimuljo, 1996)

Berdasarkan berat jenis agregat dibedakan menjadi 3 yaitu : agregat normal berat jenisnya $2500-2700 \mathrm{~kg} / \mathrm{m}^{3}$, agregat berat memiliki berat jenis $2800 \mathrm{~kg} / \mathrm{m}^{3}$ atau lebih, agregat ringan memiliki berat jenis tidak melebihi $2000 \mathrm{~kg} / \mathrm{m}^{3}$. 
Gradasi agregat adalah distribusi ukuran butiran dari agregat. Bila butiran-butiran agregat mempunyai ukuran yang sama (seragam) volume pori akan besar. Sebaliknya bila ukuran-ukuran butirannya bervariasi maka volume pori akan menjadi kecil. Hal ini karena butiran yang kecil mengisi pori di antara butiran yang lebih besar, sehingga pori-pori menjadi sedikit dengan kata lain kemampatan tinggi (Tjokrodimuljo, 1996).

Dalam SNI 03-2834-2000 yang di adopsi dari British Standard gradasi agregat halus dibagi menjadi 4 yaitu menurut pasir halus (zone I), agak halus (zone II), agak kasar (zone III) dan kasar (zone IV, selengkapnya disajikan pada Tabel 2.1 dan gradasi agregat kasar sesuai Tabel 2.2.

Tabel 2.1 Gradasi agregat halus

\begin{tabular}{|c|c|c|c|c|}
\hline \multirow{2}{*}{$\begin{array}{c}\text { Lubang } \\
\text { ayakan } \\
(\mathbf{m m})\end{array}$} & \multicolumn{4}{|c|}{ Persen ber at butir yang lewat ayakan } \\
\cline { 2 - 5 } & Zone I & Zone II & Zone III & Zone IV \\
\hline 10 & 100 & 100 & 100 & 100 \\
\hline 4.8 & $90-100$ & $90-100$ & $90-100$ & $95-100$ \\
\hline 2.4 & $60-95$ & $75-100$ & $85-100$ & $95-100$ \\
\hline 1.2 & $30-70$ & $55-90$ & $75-100$ & $90-100$ \\
\hline 0.6 & $15-34$ & $35-59$ & $60-79$ & $80-100$ \\
\hline 0.3 & $5-20$ & $8-30$ & $12-40$ & $15-50$ \\
\hline 0.15 & $0-10$ & $0-10$ & $0-10$ & $0-15$ \\
\hline
\end{tabular}

Sumber: Mulyono, 2003

Tabel 2.2 Gradasi agregat kasar

\begin{tabular}{|c|c|c|}
\hline \multirow{2}{*}{ Lubang ayakan } & \multicolumn{2}{|c|}{ Persen berat yang lewat ayakan } \\
\cline { 2 - 3 } & \multicolumn{2}{|c|}{ Besar butir maksimum } \\
\cline { 2 - 3 } & $40 \mathrm{~mm}$ & $20 \mathrm{~mm}$ \\
\hline 40 & $95-100$ & 100 \\
\hline 20 & $30-70$ & $95-100$ \\
\hline 10 & $10-35$ & $25-100$ \\
\hline 4.8 & $0-5$ & $0-10$ \\
\hline
\end{tabular}

Sumber: Mulyono, 2003 
Kadar air pada suatu agregat perlu diketahui untuk menghitung jumlah air yang diperlukan dalam campuran beton dan untuk mengetahui berat satuan agregat. Keadaan jenuh kering permukaan Saturated Surface Dry (SSD) pada agregat perlu diupayakan untuk mengkondisikan kebasahan agregat yang hampir sama dengan agregat dalam beton, sehingga agregat tidak menambah atau mengurangi air dari pasta.

Agregat halus kandungan lumpurnya tidak boleh lebih dari $5 \%$ (ditentukan terhadap berat kering). Yang diartikan dengan lumpur adalah bagian-bagian yang dapat melalui ayakan $0.063 \mathrm{~mm}$, jika lebih dari $5 \%$ maka agregat harus dicuci. Pada agregat kasar kandungan lumpurnya tidak boleh mengandung lumpur lebih dari 1\% (ditentukan terhadap berat kering).

\subsubsection{Air}

Fungsi air pada campuran beton adalah untuk membantu reaksi kimia yang menyebabkan berlangsungnya proses pengikatan serta sebagai pelicin antara campuran agregat dan semen agar mudah dikerjakan dengan tetap menjaga workabilitas.

Air diperlukan pada pembentukan semen yang berpengaruh terhadap sifat pengerjaan beton (Workability), Kekuatan, Susut dan keawetan beton. Air yang diperlukan untuk bereaksi dengan semen hanya sekitar $25 \%$ dari berat semen saja, namun dalam kenyataannya nilai faktor air semen (f.a.s) yang dipakai sulit jika kurang dari 35\%. Kelebihan air dari jumlah yang dibutuhkan dipakai sebagai pelumas, tambahan air ini tidak terlalu banyak karena kekuatan beton menjadi rendah dan beton menjadi keropos. Kelebihan air ini di tuang (bleeding) yang kemudian menjadi buih dan terbentuk suatu selaput tipis (laitance). Selaput tipis ini akan mengurangi lekatan antara lapis-lapis beton dan merupakan bidang sambung yang lemah (Mulyono, 2003).

\subsection{Kuat Tekan Beton}

Kekuatan tekan merupakan salah satu kinerja utama beton. Kekuatan tekan adalah kemampuan beton untuk dapat menerima gaya per satuan luas. Nilai kekuatan beton diketahui dengan melakukan pengujian kuat tekan terhadap benda uji silinder ataupun kubus pada umur 28 hari yang dibebani dengan gaya tekan sampai mencapai beban maksimum. Beban maksimum didapat dari pengujian dengan menggunakan alat Compression Testing Machine.

\subsection{Benda Uji}

Sebelum dilaksanakan pengecoran, bahan dasar pembentuk beton harus dalam kondisi selesai ditimbang dalam kondisi SSD (Saturated Surface Dry). Selanjutnya masukKan agregat kasar, Agregat halus, semen dan air dan proses pengadukan dilaksanakan menggunakan molen, setelah bahan dasar 
merata dalam adukan dilakukan pengukuran workability beton segar dengan alat kerucut Abrams. Dalam hal ini kontrol nilai slump harus dapat dibuktikan, apakah sudah memenuhi syarat sesuai dengan yang direncanakan. Setelah nilai slump tercapai, maka selanjutnya nilai adukan beton segar dapat dimasuKkan kedalam cetakan benda uji yang berbentuk kubus dan silinder.

\subsubsection{Benda Uji Kubus}

Di Indonesia Peraturan Beton Bertulang Indonesia mulai dikenal pada Tahun 1955, namun pemakaiannya masih sangat terbatas, pedoman konstruksi Beton Bertulang Indonesia yang disusun oleh Ir. Sutami berhasil diterbitkan oleh Badan Penerbit Pekerjaan Umum Tahun 1956, namun penggunaannya juga terbatas pada lingkup pekerjaan umum. Peraturan tersebut kemudian diperbaharui menjadi Peraturan Beton Bertulang Indonesia (PBI 1971). Dalam peraturan beton ini kuat tekan beton untuk struktur banguan ditentukan oleh benda uji kubus $15 \mathrm{~cm} \times 15 \mathrm{~cm} \times 15 \mathrm{~cm}$ yang disimbolkan dengan inisial huruf $\mathrm{K}$ diikuti dengan nilai kuat tekan rencana dalam satuan $\mathrm{kg} / \mathrm{cm}^{2}$. Dalam penelitian ini notasi kuat tekan berdasarkan benda uji kubus dinyatakan dengan $f^{\prime} c k$.

\subsubsection{Benda Uji Silinder}

Dengan berkembangnya teknologi dan penggunaan bahan baru dan juga permasalahan karena kondisi alam dan lingkungan, para ahli beton sepakat untuk memprbaharui PBI 1971 dengan Standar Tata Cara Penghitungan Struktur Beton Untuk Bangunan Gedung, (SK SNI T-15-1991-03, SNI 032847-2002).

Dalam SK SNI T-15-1991-03 dan SNI 03-2847-2002 kekuatan material beton dinyatakan oleh kuat tekan benda uji berebentuk silinder dengan notasi f'c dalam satuan Mega Pascal (MPa). Silinder standar berukuran diameter $15 \mathrm{~cm}$ dan tinggi $30 \mathrm{~cm}$ yang terbuat dari baja atau besi tuang. Benda uji silinder dibuat dengan cara yang sama dengan benda uji kubus.

\subsection{Persamaan Regresi}

Persamaan regresi adalah persamaan matematika yang memungkinkan membuat prediksi atau ekpektasi nilai suatu peubah terikat atas variasi nilai satu atau lebih nilai peubah bebas (Kurniawan, 2008). Regresi dikatakan linear apabila hubungan antara peubah bebas dan peubah tak bebas adalah linear, sedangkan apabila hubungan antara peubah bebas dan tak bebas tidak linear, maka regresi dikatakan regresi nonlinear. Hubungan antara peubah bebas dan peubah tak bebas dapat dikatakan linear apabila diagram pencar data dari peubah-peubah mendekati pola garis lurus.

Persamaan umum regresi linear sederhana adalah sebagai berikut : 


$$
\mathbf{Y}=\mathbf{a}+\mathbf{b X}
$$

Dimana :

$\mathrm{Y}=$ Subjek yang diprediksikan.

$\mathrm{X}=$ Subjek pada variable independen yang mempunyai nilai tertentu

Nilai a dan b dapat dicari dengan menggunakan rumus berikut :

$$
\begin{aligned}
& a=\frac{\left(\sum Y_{i}\right)\left(\sum X_{i}^{2}\right)-\left(\sum X_{i}\right)\left(\sum Y_{i} X_{i}\right)}{n\left(\sum X_{i}^{2}\right)-\left(\sum X_{i}\right)^{2}} \\
& b=\frac{n\left(\sum X_{i} Y_{i}\right)-\left(\sum X_{i}\right)\left(\sum Y_{i}\right)}{n\left(\sum X_{i}^{2}\right)-\left(\sum X_{i}\right)^{2}}
\end{aligned}
$$

Untuk melihat seberapa kuat hubungan antara variabel dependen dan independen dapat ditentukan berdasarkan koefisien korelasi (r). Secara umum Nilai r berkisar antara (+1) sampai (-1). Untuk melihat seberapa besar kontribusi keragaman variabel independent memberi pengaruh terhadap variabel dependen dinyatakan dengan koefisien Determinasi $(R)=r^{2}$.

$$
\begin{aligned}
& r=\frac{\sum_{i=1}^{n} x_{i} y_{i}-\left(\sum_{i=1}^{n} x_{i}\right)\left(\sum_{i=1}^{n} y_{i}\right)}{\sqrt{\left[\sum_{i=1}^{n} x_{i}^{2}-\left(\sum_{i=1}^{n} x_{i}\right)^{2}\right]\left[\sum_{i=1}^{n} y_{i}^{2}-\left(\sum_{i=1}^{n} y_{i}\right)^{2}\right]}} \\
& R=r^{2}
\end{aligned}
$$

\section{METODE PENELITIAN}

\subsection{Diagram Alir Penelitian}

Adapun diagram alir penelitian adalah sebagai berikut : 


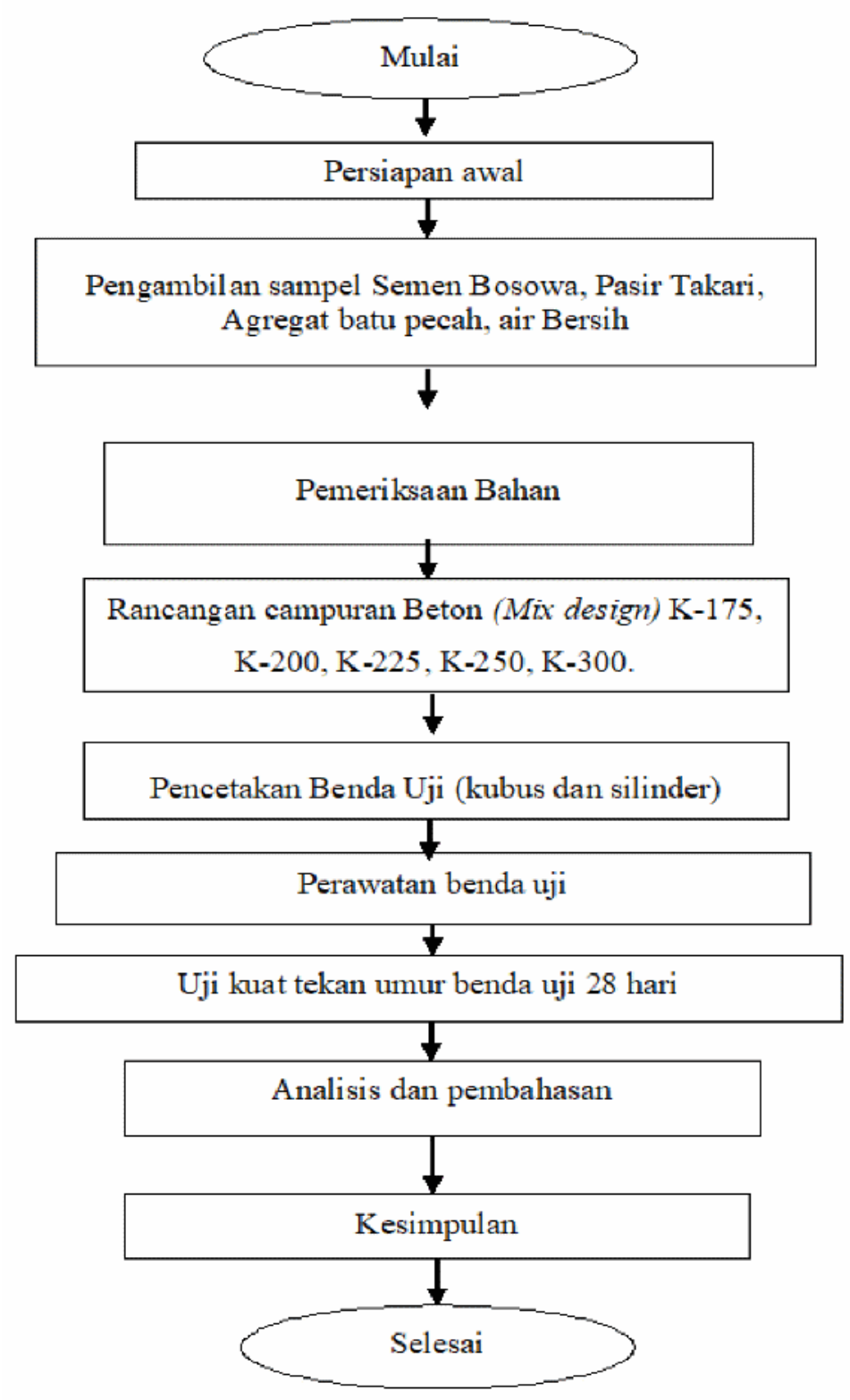

Gambar 3.1 Diagram Alir Penelitian

\subsection{Pembuatan, Perawatan dan Pengujian Kuat Tekan Benda Uji}

Pembuatan sampel atau benda uji berjumlah 30 buah dengan klasifikasi 15 buah benda uji kuat tekan silinder dan 15 buah benda uji kuat tekan kubus. Masing-masing mutu beton disiapkan 3 benda uji yaitu untuk mutu beton K-175, K-200, K-225, K-250 dan K-300. Perawatan benda uji dalam penelitian ini dilakukan dengan cara perendaman selama 28 hari di laboratorium setelahnya dilakukan uji kuat tekan. 


\section{HASIL DAN PEMBAHASAN}

Penelitian ini merupakan studi eksperimen yang dilaksanakan di Laboratorium Bahan Konstruksi Dinas Pekerjaan Umum Pemerintah Provinsi Nusa Tenggara Timur.

\subsection{Pemeriksaan Bahan Lolos Saringan Nomor 200 untuk Agregat Halus dan Kasar}

Pengujian ini bertujuan untuk mengetahui kadar lumpur atau bagian butir agregat yang lebih kecil dari 70 mikron $(0,075 \mathrm{~mm})$ atau lolos saringan Nomor 200, dimana menurut SII.0052 untuk agregat halus nilai tidak boleh lebih dari 5\% dan agregat kasar tidak boleh lebih dari 1\% (Mulyono, 2003).

Hasil pemeriksaan agregat dalam penelitian ini mendapatkan nilai bagian yang lolos saringan Nomor 200 untuk agregat halus sebesar 4.8\% dan agregat kasar 0,985\%. Kedua hasil pemeriksaan ini menunjukkan bahwa kedua jenis agregat telah memenuhi syarat.

\subsection{Pemeriksaan Berat Jenis dan Penyerapan Air Agregat Halus dan Agregat Kasar}

Pemeriksaan berat jenis dan penyerapan air untuk agregat kasar menggunakan Standar SNI 03 1969 - 1990 dan untuk agregat halus menggunakan Standar SNI 03 - 1970 - 1990. Hasil pemeriksaaan berat jenis (SSD) dan penyerapan air untuk agregat kasar masing-masing 2,656 dan 0,76\%. Sedangkan agregat halus berat jenis (SSD) dan penyerapan airnya masing-masing 2,618 dan 2,57\%.

\subsection{Analisis Saringan Agregat Halus dan Agregat Kasar}

Analisis saringan bertujuan untuk mengetahui distribusi butiran (gradasi) agregat agregat halus maupun agregat kasar sesuai Standar SNI 03 - 1968 - 1990. Hasil pemerikasan analisis saringan agregat kasar dan halus disajikan dengan grafik pada Gambar 4.1 dan Gambar 4.2.
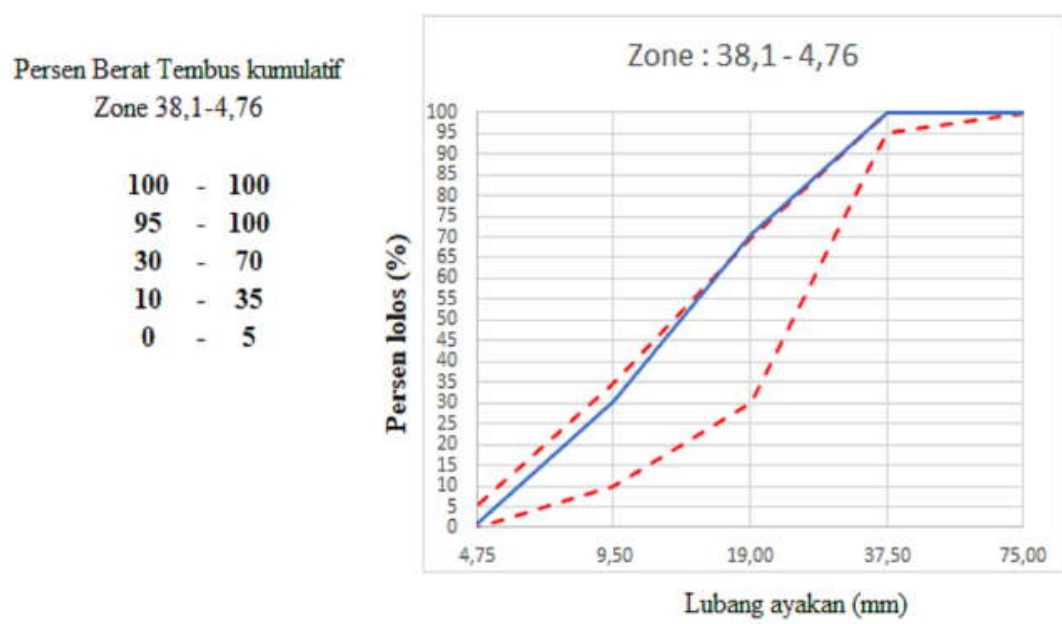

Gambar 4.1 Grafik hasil analisa saringan agregat kasar 


Persen Berat Tembus kumulatif
Zone 1
$\begin{aligned} & 100-100 \\ & 90-100 \\ & 60-95 \\ & 30-70 \\ & 15-34 \\ & 5-20 \\ & 0-10\end{aligned}$

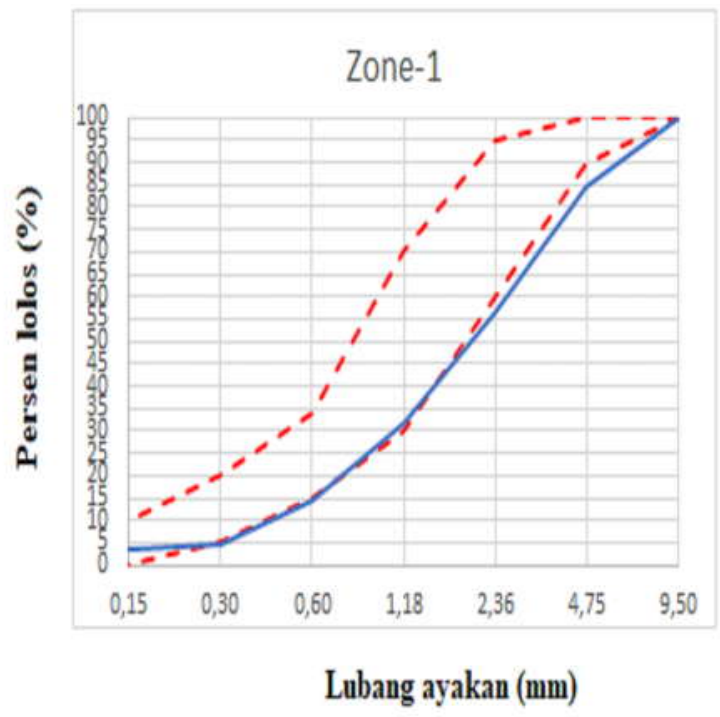

Gambar 4.2 Grafik hasil analisa saringan agregat halus

Gradasi agregat halus tampak keluar dari batasan zone namun kondisi ini adalah kondisi paling mendekati dari 3 zone gradasi lainnya. Kondisi ini dtetap dipakai untuk mepertahankan kondisi alami dari agregat tersebut.

\subsection{Analisa Nilai Keausan Agregat Kasar}

Pemeriksaan nilai keausan agregat kasar menggunakan standar SNI 03 - 2417- 1991 yaitu standar pengujian keauasan agregat dengan Mesin Abrasi Los Angeles. Pengujian ini dilakukan untuk mengetahui angka keausan yang dilakukan dengan membuat perbandingan antara berat bahan aus lolos saringan No. $12(1,7 \mathrm{~mm})$ terhadap berat semula yang dinytakan dalam persen. Hasil pemeriksaan analisis keausan agregat kasar dalam penelitian ini didapat nilai keausan sebesar 28,92\% sudah memenuhi syarat untuk mutu beton normal yang dibatasi tidak melebihi $40 \%$.

\subsection{Komposisi Campuran untuk Setiap Mutu Beton}

Komposisi campuran dirancang menggunakan Standar SNI 03-2834-2000 yaitu Standar Tata Cara Pembuatan Campuran Beton Normal. Komposisi campuran untuk $1 \mathrm{~m}^{3}$ setiap mutu beton disajikan pada Tabel 4.1 dengan nilai slump rencana sesuai Tabel 4.2. 
Tabel 4.1 Komposisi Untuk $1 \mathrm{~m}^{3}$

\begin{tabular}{|c|c|c|c|c|c|c|}
\hline \multirow{2}{*}{ Komposis } & \multirow{2}{*}{ Satuan } & \multicolumn{5}{|c|}{ Tipe K } \\
\cline { 3 - 7 } & & K-175 & K-200 & K-225 & K-250 & K-300 \\
\hline Agregat Halus & $\mathrm{kg}$ & 954.398 & 924.850 & 898.138 & 871.202 & 812.362 \\
\hline Agregat Kasar & $\mathrm{kg}$ & 1091.069 & 1100.657 & 1112.853 & 1124.084 & 1137.295 \\
\hline Semen & $\mathrm{kg}$ & 366.667 & 387.037 & 401.923 & 418.000 & 464.444 \\
\hline Air & $\mathrm{kg}$ & 222.366 & 221.956 & 221.587 & 221.214 & 220.398 \\
\hline
\end{tabular}

Sumber: Hasil Analisis

Tabel 4.2 Nilai slump rencana

\begin{tabular}{|c|c|}
\hline K-Rencana & Nilai slump (mm) \\
\hline K-175 & 38 \\
\hline K-200 & 40 \\
\hline K-225 & 45 \\
\hline K-250 & 45 \\
\hline K-300 & 40 \\
\hline
\end{tabular}

Sumber: Has il Analisis

Benda uji dicetak 3 buah untuk setiap mutu beton dalam bentuk silinder dan dalam bentuk kubus. Setelah dilakukan pencetakan dan perawatan sampai umur benda uji 28 hari selanjutnya akan dilakukan uji kuat tekan.

\subsection{Hasil Pengujian Kuat Beton pada Umur 28 Hari}

Hasil pengujian kuat tekan untuk setiap mutu beton disajikan pada Tabel 4.3 dan utuk kebutuhan analisis dalam tabel disajikan rario kuat tekan beton berdasarkan benda uji kubus dan silinder. 
Hasil perhitungan menggunakan data hasil pengujian benda uji secara individual ratio $f^{\prime} c / f^{\prime} c k$ bernilai $0,82-0,93$, berdasarkan rata-rata tiap mutu beton bernilai $0,76-0,87$ dan berdasarkan rata-rata untuk seluruh mutu beton benilai 0,83. Nilai ini sama dengan yang dicantumkan dalam PBI 1971.

\subsection{Analisis Regresi}

Analisis regresi dilakukan untuk mengetahui hubungan nilai kuat tekan benda uji silinder sebagai variabel terikat dan benda uji kubus sebagai variabel bebas dalam bentuk fungsi matematis. Dalam penelitian ini analisis regresi menggunakan analisis regresi linear sederhana (Simple regression) dengan data variabel bebas dan varibel terikat seperti pada Tabel 4.4.

Tabel 4.3 Ratio kuat tekan berdasarkan benda uji kubus dan silinder umur 28 hari

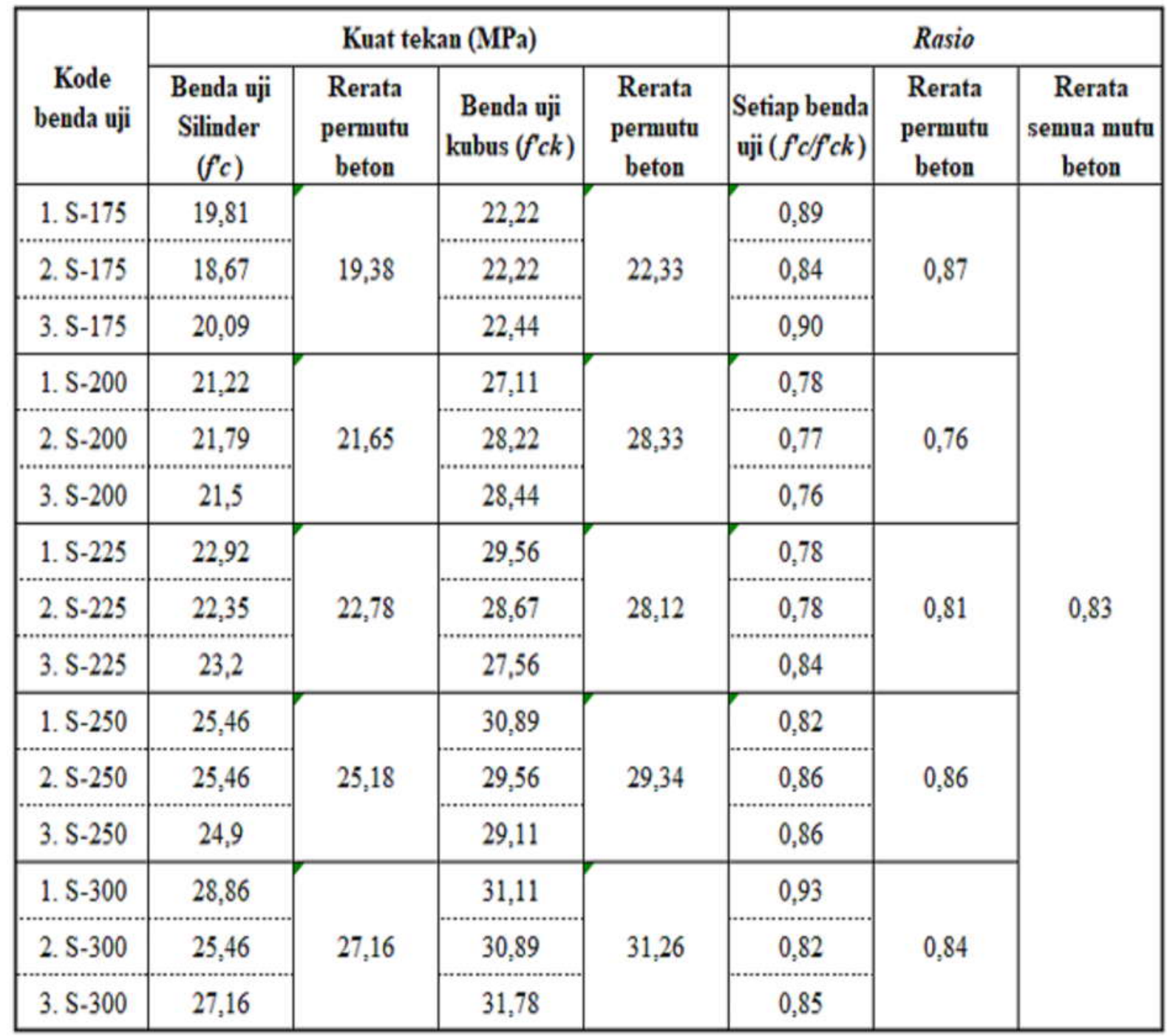

Sumber: Hasil Analisis 
Tabel 4.4 Nilai varibel bebas dan variabel terikat

\begin{tabular}{|c|c|c|}
\hline Mutu Beton & $\begin{array}{c}\text { Varibel bebas } \\
\text { (Kuat tekan benda } \\
\left.\text { uji Kubus, } \boldsymbol{f}^{\prime} \mathbf{c k}\right) \\
\text { (MPa) }\end{array}$ & $\begin{array}{c}\text { Varibel terikat (Kuat } \\
\text { tekan benda uji } \\
\text { Silinder, } \boldsymbol{f}^{\prime} \mathbf{c} \text { ) } \\
\text { (MPa) }\end{array}$ \\
\hline 175 & 22,33 & 19,38 \\
\hline 200 & 28,33 & 21,65 \\
\hline 225 & 28,12 & 22,78 \\
\hline 250 & 29,34 & 25,18 \\
\hline
\end{tabular}

Sumber: Hasil Analisis

Persamaan regresi linear sederhana pada penelitian ini dalam persamaan matematis yang diharapkan mengikuti pola persamaan : $\mathrm{Y}=\mathrm{a}+\mathrm{bX}$, dimana $\mathrm{Y}=f^{\prime} c$ dan $\mathrm{X}=f^{\prime} c k$. Nilai $\mathrm{a}$ dan $\mathrm{b}$ ditentukan berdasarkan formula sebagai berikut :

$$
a=\frac{\left(\sum Y_{i}\right)\left(\sum X_{i}^{2}\right)-\left(\sum X_{i}\right)\left(\sum Y_{i} X_{i}\right)}{n\left(\sum X_{i}^{2}\right)-\left(\sum X_{i}\right)^{2}} ; b=\frac{n\left(\sum X_{i} Y_{i}\right)-\left(\sum X_{i}\right)\left(\sum Y_{i}\right)}{n\left(\sum X_{i}^{2}\right)-\left(\sum X_{i}\right)^{2}}
$$

Tabel 4.5 Tabel Menghitung Persamaan Regresi Linear

\begin{tabular}{|c|c|c|c|c|c|}
\hline $\mathbf{N o}$ & $\mathbf{X i}$ & $\mathbf{Y i}$ & $\mathbf{X i Y i}$ & $\mathbf{X}^{\mathbf{2}}$ & $\mathbf{Y}^{\mathbf{2}}$ \\
\hline $\mathbf{1}$ & 22,33 & 19,38 & 432,76 & 498,63 & 375,58 \\
\hline $\mathbf{2}$ & 28,33 & 21,65 & 613,20 & 802,59 & 468,51 \\
\hline $\mathbf{3}$ & 28,12 & 22,78 & 640,32 & 790,45 & 518,70 \\
\hline $\mathbf{4}$ & 29,34 & 25,18 & 738,66 & 860,54 & 634,03 \\
\hline $\mathbf{5}$ & 31,26 & 27,16 & 849,02 & 977,19 & 737,67 \\
\hline $\mathbf{\Sigma}$ & 139,37 & 116,14 & 3273,95 & 3929,40 & $\mathbf{2 7 3 4 , 4 9}$ \\
\hline
\end{tabular}

Sumber: Hasil Anal isis 


$$
\begin{aligned}
& a=\frac{\left(\sum Y_{i}\right)\left(\sum X_{i}^{2}\right)-\left(\sum X_{i}\right)\left(\sum Y_{i} X_{i}\right)}{n\left(\sum X_{i}^{2}\right)-\left(\sum X_{i}\right)^{2}}=\frac{(116,14)(3929,40)-(139,37)(3237,95)}{5(3929,40)-(139,37)^{2}}=0,312 \\
& b=\frac{n\left(\sum X_{i} Y_{i}\right)-\left(\sum X_{i}\right)\left(\sum Y_{i}\right)}{n\left(\sum X_{i}^{2}\right)-\left(\sum X_{i}\right)^{2}} \quad=\frac{5(3237,95)-(139,37)(116,14)}{5(3929,40)-(139,37)^{2}} \quad=0,822
\end{aligned}
$$

Sehingga persamaan regresi yang didapat :

$\mathrm{Y}=0,312+0,822 \mathrm{X}$ atau $f^{\prime} c=0,312+0,822 f^{\prime} c k ; f^{\prime} c$ dan $f^{\prime} c k$ dalam MPa dengan nilai r yaitu :

$r=\left(\frac{b\left(n\left(\sum X_{i} Y_{i}\right)-\left(\sum X_{i}\right)\left(\sum Y_{i}\right)\right)}{\left(n\left(\sum Y_{i}^{2}\right)-\left(\sum Y_{i}\right)^{2}\right)}\right)^{1 / 2}=\left(\frac{0,822(5(3273,95)-(139,37)(116,14))}{\left(5(2734,49)-(116,14)^{2}\right)}\right)^{1 / 2}=0,905$ dan $\mathrm{R}=\mathrm{r}^{2}=0,905^{2}=0,819$

Koefisien korelasi (r) menyatakan kuatnya hubungan antara variabel dapat diketahui berdasarkan penyebaran titik-titik pertemuan antara dua variabel misalnya $\mathrm{X}$ dan $\mathrm{Y}$ yang digambarkan dalam diagram pencar (scatterplot). Koefisien korelasi (r) yang didapat 0.905 , menunjukan hubungan antara kedua variabel sangat kuat. Sugiyono (2009) menyatakan nilai $r$ antara 0.80-1,00 menunjukkan hubungan yang sangat kuat antara kedua variabel. Koefisien determinasinya $R=r^{2}=0.819$ atau $81,90 \%$ mengindikasikan bahwa Nilai variabel terikat (kuat tekan beton berdasarkan benda uji silinder) dipengaruhi oleh $81,90 \%$ oleh nilai variabel bebas (kuat tekan beton berdasarkan benda uji kubus) dan $18,10 \%$ ditentukan oleh faktor lain.

Grafik regresi linear hubungan kuat tekan kubus dan silinder ditampilkan pada gambar 4.3.

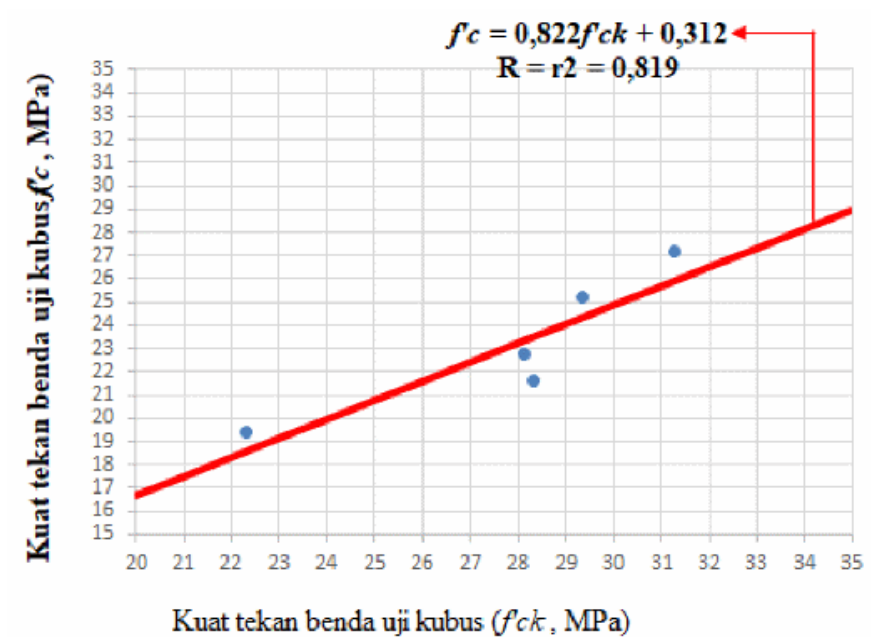

Gambar 4.3 Grafik konversi kuat tekan beton benda uji kubus ke silinder 
Dengan memasukkan nilai kuat tekan beton secara acak yang diasumsikan hasil uji benda uji kubus kedalam persamaan regresi linear hasil analisis hasil penelitian $f^{\prime} c=0.822 f^{\prime} c k+0.312$ dan formula konversi $f^{\prime} c=\left[0,76+0,2 \log \left(f^{\prime} c k / 15\right)\right] . f^{\prime} c k$ (Mulyono, 2004 dan Nugraha et al., 2007) selanjutnya hasilnya dikomparasi seperti disajikan pada Tabel 4.6.

Tabel 4.6 Komparasi formula konversi kuat tekan beton antara benda uji kubus dan silinder

\begin{tabular}{|c|c|c|c|c|}
\hline$f c k$ & $\begin{array}{c}\left(f^{\prime} c\right)_{A}= \\
0.822 f^{\prime} c k+0.312\end{array}$ & $\begin{array}{c}\left(f^{\prime} c\right)_{R}=[0,76+0,2 \log \\
\left.\left(f^{\prime} c k / 15\right)\right] f^{\prime} c k\end{array}$ & $\left(f^{\prime} c\right) A-\left(f^{\prime} c\right) R$ & $\left|\left(f^{\prime} c\right) A-\left(f^{\prime} c\right) R\right|$ \\
\hline $\mathrm{MPa}$ & $\mathrm{MPa}$ & $\mathrm{MPa}$ & $\mathrm{MPa}$ & $\mathrm{MPa}$ \\
\hline 17,50 & 14,70 & 13,53 & 1,16 & 1,16 \\
\hline 20,00 & 16,75 & 15,70 & 1,05 & 1,05 \\
\hline 22,50 & 18,81 & 17,89 & 0,91 & 0,91 \\
\hline 25,00 & 2086 & 20,11 & 0,75 & 0,75 \\
\hline 27,50 & 22,92 & 22,35 & 0,57 & 0,57 \\
\hline 30,00 & 24,97 & 24,61 & 0,37 & 0,37 \\
\hline 32,50 & 27,03 & 26,88 & 0,14 & 0,14 \\
\hline 35,00 & 29,08 & 29,18 & $-0,09$ & 0,09 \\
\hline 37,50 & 31,14 & 31,48 & $-0,35$ & 0,35 \\
\hline 40,00 & 33,19 & 33,81 & $-0,62$ & 0,62 \\
\hline 42,50 & 35,25 & 36,14 & $-0,90$ & 0,90 \\
\hline 45,00 & 37,30 & 38,49 & $-1,19$ & 1,19 \\
\hline 47,50 & 3936 & 40,86 & $-1,50$ & 1,50 \\
\hline 50,00 & 41,41 & 43,23 & $-1,82$ & 1,82 \\
\hline \multicolumn{2}{|r|}{ Rata-rata } & & & 0,82 \\
\hline
\end{tabular}

\section{Sumber : Hasil analisis}

Tabel komparasi diatas menunjukkan bahwa perbedaan hasil konversi secara rata-rata absolut sebesar 0,82 MPa. Formulasi hasil penelitian cendrung lebih besar untuk hasil uji kubu sampai nilai kuat tekan 32,5 MPa dan selebihnya hasilnya lebih kecil.

\section{KESIMPULAN}

Dari hasil penelitian yang sudah dilaksanakan dapat diambil kesimpulan sebagai berikut:

1. Hasil ratio rata-rata hubungan kuat tekan benda uji kubus dan silinder beton dengan agregat Pulau Timor sebesar 0.83 dan dalam fungsi regresi linear dengan persamaan $f^{\prime} c=0,822 f^{\prime} c k+0,312$, dimana $f^{\prime} c$ dan $f^{\prime} c k$ dalam MPa dengan nilai slump 30-60 mm dengan Koefisien korelasi (r) $=0.905$ dan koefisien determinasi $\left(\mathrm{r}^{2}\right)=0.819$, menunjukkan $81,90 \%$ nilai kuat tekan beton $f^{\prime} c$ dapat 
ditentukan berdasarkan hasil pengujian benda uji kubus dan $18,10 \%$ ditentukan oleh faktor lain. Perlu dilakukan penelitian lanjutan dengan mempertimbangkan faktor lain yang mempengaruhi sehingga nilai determinasinya bisa meningkat.

2. Rata-rata faktor konversi hasil penelitian sebesar 0,83 sama dengan yang dicantumkan dalam PBI 1971 dan formulasi konversi hasil penelitian : $f^{\prime} c=0,822 f^{\prime} c k+0,312$ menunjukkan rerata perbedaan absolut sebesar 0,82 MPa atau 3,17\%. Dalam penelitian ini agregat yang digunakan spesifik dari Quarry Takari saja, sehingga perlu dilakukan penelitian lanjutan untuk lokasi quarry lain di Pulau Timor untuk menentukan formula konversi yang berlaku general untuk lokasi Pulau Tomor.

\section{DAFTAR PUSTAKA}

Anonimous, 2000, Tata Cara Pembuatan Rencana Campuran Beton Normal (SNI 03-2834-2000), Badan Standardisasi Nasional, Bandung.

Anonimous, 2002, Tata Cara Perhitungan Struktur Beton Untuk Bangunan Gedung, Badan Standar Nasional, Bandung.

Anonimous, 1991, Metode Pengujian Keausan Agregat Dengan Mesin Abrasi Los Angeles (SNI 032417-1991), Badan Standar Nasional, Bandung.

Anonimous, 1990, Metode Pengujian Analisis Saringan Agregat Halus dan Kasar (SNI 03-1968-1990), Badan Standardisasi Nasional, Bandung.

Anonimous, 1990, Metode Pengujian Berat Jenis dan Penyerapan Air Agregat Kasar (SNI 03-19691990), Badan Standardisasi Nasional, Bandung.

Anonimous, 1990, Metode Pengujian Berat Jenis dan Penyerapan Air Agregat Halus (SNI 03-19701990), Badan Standardisasi Nasional, Bandung.

Anonimous, 1971, Peraturan Beton Bertulang Indonesia (NI 2), Yayasan Lembaga Penyelidikan Masalah Bangunan, Bandung

Aji, P, Et All., 2010, Pengendalian Mutu Beton, Institut Sepuluh Nopember Surabaya, Surabaya.

Indra, E., 1999, Angka Konversi Specimen Kubus Dan Silinder dalam Variasi Mutu Beton Normal, Jurnal Teknik Sipil Universitas Batam. Batam.

Ismail, F.A., 2009, Studi Kuat Tekan Beton campuran $1: 2: 3$ Berdasarkan Lokasi Pengambilan Agregat Di Sumatra Barat, Jurnal Teknik Sipil Universitas Andalas, Sumatra.

Mulyati, D., 2011, Korelasi Nilai Kuat Tekan Beton Antara Hamer Test dan Compression Test Pada Benda Uji Silinder dan Core Drill, Universitas Diponegoro, Semarang.

Mulyono, T., 2003, Teknologi Beton, Penerbit Andi, Yoyakarta.

Nugrara, P., Antoni, 2007, Teknlogi Beton, Dari Material, Pembuatan, Ke Beton Kinerja Tinggi, Penerbit Andi, Surabaya

Sembiring, TJ., 2002, Beton Bertulang, Bandung.

Sudjana., 2005, Metode Statistika, Tarsito, Bandung.

Sugiyono., 2009, Statatistika Untuk Penelitian, Alfabeta, Bandung. 